\title{
CULTURE AND CULTURAL LANDSCAPES AS FUNCTIONAL MATRICES FOR WILDERNESS - AND VICE VERSA
}

TILL MEYER

Balanstr. 191, 81549 München, Germany

Corresponding author: till.m@arcor.de

\section{Preparing for the 10th World Wilderness Congress, participants in Germany learn about the cultural dimensions of conservation.}

Wilderness received special attention at the 10th World Wilderness Congress (WILD 10), which took place October 4-10 October in Salamanca, Spain. Prior to this congress, a series of events dubbed "The trail to Salamanca" marked preparatory efforts to sharpen the debate about wilderness in Europe. One of the events on this "trail" was a "Wilderness Seminar" held on November 5 to 8, 2012 in the German City of Potsdam. The seminar, which was jointly organized by the Brandenburg Wilderness Foundation and the international WILD Foundation, was attended by 33 participants from 10 nations (Germany, France, Great Britain, the Czech Republic, Kazakhstan, South Africa, Pakistan, Slovakia, the Ukraine and the USA) who considered the "first training component of the WILD 10 process".

Early during this event, a broad perception surfaced that wilderness would always remain a kind of antithesis to culture. Indeed one can think about this in terms of the connotation of the word "culture" in "agriculture", "horticulture" and "silviculture" as standing for "everything manmade", for "improvement" and "refinement".

This is not trivial and often makes for the key dilemma in conservation: in many regions (and "cultures") culture is considered to be something desirable and wilderness therefore undesirable. Thus the advocacy of wilderness and the conservation of free evolving natural processes often face superstition and opposition. Therefore this paper attempts to take the bite out of the perceived wilderness versus culture period after dichotomy. In the course of the of Potsdam seminar it was demonstrated very well that wilderness and culture mutually depend on one another. Due to the high profile of the presenters, such as Vance Martin, President of the WILD Foundation, the event turned out to be an account of the components of the global wilderness movement and quite an eye opener about future strategies for protecting wilderness. The seminar in Potsdam substantiated in many ways that the principle strategies for protecting wilderness are cultural based.

The first example of this is where this seminar was held. The state of Brandenburg (one of 16 of the Federal
Republic of Germany) is located in the terrain of former Prussia, which is the political predecessor of the Third Reich and the state famous for its grandiose castles and infamous for its past bellicose culture. Absolutist kings and emperors of the 18th, 19th and early 20th century established Prussia as a global power next to Great Britain, France, Austria and Russia by developing an "unusually well-organized and effective army". In the 20th century, monarchy gave way to the dictatorship of the "Third Reich", then to World War II and finally the Cold War. For this the state of Brandenburg provided vast areas of military training grounds. In 1994, just after the end of the Cold War, the Brandenburg Wilderness Foundation was established in order take responsibility for these former military areas, which currently cover an area of 12,800 hectares.

It was during this period (in 1992) that conservation in Germany gained prominence when Hans Bibelriether, the first director of Germany's first National Park, coined the catchy motto "let nature be" for what later became internationally known as the "non-intervention management" idea of wilderness. Consequently for the Brandenburg Foundation wilderness means "unused landscapes not regulated and managed by humans where nature can develop following its own rules." according to Hans Joachim-Mader, who chairs the Brandenburg Wilderness Foundation.

In their joint foreword to the seminars both Vance Martin and Hans-Joachim Mader acknowledge the cultural value of this conversion: "After several centuries of bellicose, totalitarian regimes (...) large tracts of country are now being allowed to revert back to a wild state and Mother Nature is the new regime (...) This is a major and long-term change, which is occurring not only in the landscape but also, and most importantly, in the minds of people. This is culture, this is progress; this is making history, and yes, lest we forget, this is wilderness at work."

This enthusiastic exclamation about "making history" is not a exaggeration. Considering the close proximity of Potsdam to the capital of this nation, Berlin, the willful transformation of military training grounds into wilderness is a paradigmatic change in this nation's values. This change will receive even more attention as the landholdings near Berlin are to be displayed in a landscape wide "International Nature Exhibition". 
The idea of wilderness is pregnant with all kinds of "symbolisms" and "values" and thus a cultural phenomenon. Vance Martin pledges to take the triple value of wilderness seriously: "But what is the value in wilderness protection? If we put this question to conservationists trained in biology, the answer would probably be 'biological intactness' and 'ecosystem function'. If we ask natural resource administrators, they would maintain that socio-economic motives such as 'recreation' and 'subsistence' are valid reasons for wilderness protection. Yet another clientele requests intangible ecosystem services such as 'inspiration', 'beauty', 'mystery' and 'spirit'. So to what means and ends should we protect wilderness? The answer for The WILD Foundation clearly is: all of the above. WILD chooses a three dimensional approach to wilderness protection that includes biological, socio-economic and iconic motives".

An icon of course is a symbol, which stands for certain assumed functions. The icon "wilderness" is often associated with "richness in natural history" and "biodiversity", but also with "chaos", "destruction" and "danger", and is said to "inspire awe" and challenges our para-religious feelings, such as "sublimity." Wilderness travelers swear that exposure to wilderness has a "cleansing effect" and makes us exercise "humility" and "restraint", and questions the spreading of the "culture of convenience". In other words: wilderness is a vector which could help pave the way to certain desirable personal and societal traits. Seen more neutrally, wilderness has cultural functions, such as "shared values and practices", and "aesthetic training" (as described in Princeton University's "word-net").

These cultural functions of wilderness can be extracted using the cultural skill of communication. The seminar demonstrated that explicitly. Karl Friedrich Sinner, former director of the Bavarian Forest National Park and vice chairman of Europarc-Germany, which is the umbrella organization for all large protected areas in Germany describes the communication skill required: "Wilderness protection is most of all a question of communication, which should address both the mind and the heart (...) It is a story of many plots that need to be related. We have to relate that Urwald (natural forest) is not just about 'big trees', but mostly about different phases of development, which change yearly and often on a daily basis. We have to relate that death in nature is much more than carnivores eating herbivores. The variety of brightly-coloured fungi reveals that the life of a wild forest is largely built by agents of decomposition; the tree mushrooms, the beetles which depend on decaying wood, the many bird species that live on these insects ..."

Another presenter, Kevin Hood, Wilderness Manager of the US Forest Service in Alaska, stressed the importance of communication in wilderness conservation and that historically "the shift to a broad wilderness advocacy in American society came with John Muir, a Scottish-born naturalist and author. Muir's articles, books and his special gift of storytelling helped in creating the groundswell that eventually resulted in establishing Yosemite National Park in 1890."

One of the most primeval cultural skills, storytelling around a campfire, was basic to the foundation of WILD in 1974. According to Vance Martin, "Dr. Ian Player, a game ranger of Anglo heritage, and his Zulu mentor, Magqubu Ntombela, pioneered the first walking safaris, or 'trails', in the South African wilderness. They knew this would be the best way to connect people to themselves, one-another and foster a relationship between people and nature."

The accompanying campfire talks between members of indigenous tribes and largely Caucasian "white" scientists and conservationists was in the early days not only in marked contrast to the racial segregation practiced then but later proved to be the key to successful wilderness protection. During later years the friendly camp fire talks would evolve into systematic round table events for stakeholders preparing "wilderness management plans".

In his presentation on this subject Drummond Densham of the Wilderness Action Group of South Africa cautioned: "Extra care must be taken in South Africa to prevent local communities thinking their land is being taken over, thus producing a historical déjà-vu. In reality this does not occur in South Africa. Stakeholders around the planet should feel that they are gaining by having areas in their countries designated as wilderness." Later comments revealed that wilderness management was greatly appreciated, which for some in the audience was quite a new idea. Some even admitted that citizen participation in conservation planning was still quite poor in some European countries.

It is this kind of cultural and cross-cultural communication that made the World Wilderness Congress a success. The first one was held in Johannesburg, South Africa in 1977. Today the World Wilderness Congress is considered to be the longest running public conservation forum and platform. At the most recent WILD 9 venue in 2009 in Mexico, 1800 delegates from more then fifty nations attended.

As the recent Wilderness Congress (WILD 10) took place in Salamanca, many of the presented topics did of course originate from Europe, where the landscape is often even more fragmented than in other continents. The state of Brandenburg is a good example as it largely consists of "cultural landscapes", meaning that most of the features in the landscape are man made. Needless to say the idea of wilderness may be much more challenging to execute here than in many other countries.

In order to meet this challenge the Brandenburg foundation developed the ambitious "Ecological Corridor of South Brandenburg" near Berlin, which facilitates the migration of organisms between Poland and Germany. Wolves have recolonized the state and now count seven family units ("packs"). Systematic monitoring of this corridor revealed an increase in ground-dwelling insects (Carabidae), which in turn had positive effects on the 
breeding success of birds such as the Red-backed shrike (Lanius collurio).

The "corridor for biodiversity" according to Mader is a "result of a concerto of instruments that work well together: features in the landscape such as edges, linear structures and stepping stones connected by way of underpasses, culverts, green bridges, riparian strips and fish ladders. Great results can often be achieved by working with and enhancing existing structures. This and the continuing support of the people of Brandenburg help to constitute the underlying matrix where wildness can perpetuate itself."

This idea of a large landscape conservation system as a "matrix" to "help wilderness perpetuate itself" works both ways. Wilderness can be beneficial to cultural landscapes as wilderness is more likely to contain the original blend of faunal and floral ingredients of a particular re- gion. In addition, as the scientific report of the Bavarian Forest National Park (2009) concluded, large protected areas provide "threshold values e.g. for forest age, quantities and different dimensions of dead wood, canopy cover and nesting holes. These are the basis for a procedure, by which the conservation relevant areas within a forestry site may be identified (...) on a landscape level as well as on forest stand and individual object level."

Therefore it can be concluded that even concepts of "horticulture" and "silviculture" will benefit from the "gold standard", which is represented in terms of wilderness. The American ecologist Aldo Leopold knew this already in the 1940s as he wrote: "Each biotic providence needs its own wilderness for comparative studies of used and unused land." Consequently wilderness should not be regarded as in opposition to a cultural landscape but a vital ingredient of it. 